\title{
Single cell gel electrophoresis and its applications in different fields
}

\section{Abstract}

The Single Cell Gel Electrophoresis assay (SCGE) is a better technique for the detection of DNA damage and DNA repair in eukaryotes. First time comet assay technique was designed by Ostling \& Johanson 1 and then it was modified by Singh et al.3 There are four main steps in comet assay .These are

$$
\begin{aligned}
& \text { a. Encapsulation of cell in Agarose having low melting point. } \\
& \text { b. Lysis of cells. } \\
& \text { c. Gel electrophoresis and forth is staining and visualization. }
\end{aligned}
$$

This technique is also known as comet assay because DNA movement pattern in gel electrophoresis similar to a comet. The comet assay is use for the measurement of DNA strand breaks in eukaryotes. In this technique cell suspended in Agarose on slides and lysed with detergent to form nucleoid contain super coiled DNA attached with nuclear matrix. Comets which were made in electrophoresis detected by fluorescence microscopy, manual or mechanical methods use for scoring but now a day's mechanical methods are very useful. Comet assay have simplicity, sensitivity, speed and economical use. In this review we discuss its protocol and its applications in different fields.

Keywords: gel electrophoresis, DNA, applications, comet, microscopy
Volume 4 Issue 2 - 2017

\author{
Muhammad Fahim, Ali Ahmed, Shakeel \\ Hussain \\ Department of Pharmacy, Quaid-i-Azam University, Pakistan
}

Correspondence: Ali Ahmed, Department of Pharmacy, Quaid-i-Azam University, Islamabad 45320, Pakistan, Tel 923338619923, Email aliahmed@bs.qau.edu.pk Received: September 09, 2017 | Published: November 22,
2017
Abbreviations: SCGE, single cell gel electrophoresis assay; MGE, microgel electrophoresis; DNA, deoxyribonucleic acid; WBCs, white blood cells; PCR, polymerase chain reaction; HPLC, high-performance liquid chromatography

\section{Introduction}

The comet assay is also known as microgel electrophoresis (MGE) was first time established by Ostling \& Johanson ${ }^{1}$ for the direct exposure of DNA damage in individual cells. ${ }^{1}$ First of all cells in a thin Agarose gel on a slide (microscopic) were lysed then did electrophoresis and after that stained with a fluorescent DNA binding dye. The electric current pulled the charged DNA from the nucleus such that undisturbed and broken DNA fragments migrated further. The resulting images, which were subsequently named for their appearance as 'comets', were measured to determine the extent of DNA damage. The original method which was developed by Ostling \& Johanson ${ }^{1}$ was not very good because they were unable to remove all of the proteins from the cells. So more lysis requires, for the removal of cellular proteins and for the migration of broken duplex in gel electrophoresis. Two laboratories changed the method about five years ago by applying different denaturing conditions for the measurement of Single strand breaks in DNA.,3 The first group (3) were maximized the sensitivity for the detection of small number of strand breaks, while second laboratory focused towards the detection of subpopulations which vary in drug or radiation sensitivity. ${ }^{2}$ There has been greater interest in comet assay from past two to three years. Many papers publish on comet assay because it has very unique design for the direct determination of DNA damage in individual cells. Single cell gel electrophoresis also use to examine DNA repair

\begin{tabular}{|c|c|c|c|}
\hline $\begin{array}{l}\text { Serial } \\
\text { no }\end{array}$ & Procedures & Advantages & $\begin{array}{l}\text { Disadvantages/ } \\
\text { limitations }\end{array}$ \\
\hline I & PCR & $\begin{array}{l}\text { Easy to measure } \\
\text { gene specific } \\
\text { DNA damage }\end{array}$ & Cannot quantify \\
\hline 2 & TUNNEL & $\begin{array}{l}\text { Detect single and } \\
\text { double strand } \\
\text { brake }\end{array}$ & $\begin{array}{l}\text { Cannot differentiate } \\
\text { between necrosis and } \\
\text { apoptosis }\end{array}$ \\
\hline 3 & HPLC & $\begin{array}{l}\text { Sensitive and } \\
\text { specific for } \\
\text { quantification of } \\
\text { Thymidine }\end{array}$ & $\begin{array}{l}\text { Early elution } \\
\text { property of liquid } \\
\text { chromatography }\end{array}$ \\
\hline 4 & $\begin{array}{l}\text { Micro- } \\
\text { Nucleus Assay }\end{array}$ & $\begin{array}{l}\text { Easy to perform } \\
\text { less time } \\
\text { required }\end{array}$ & Low sensitivity \\
\hline 5 & Halo Assay & $\begin{array}{l}\text { Detect changes } \\
\text { in DNA of } \\
\text { individual cell }\end{array}$ & Low sensitivity \\
\hline 6 & FISH & $\begin{array}{l}\text { More sensitive } \\
\text { than FCM }\end{array}$ & $\begin{array}{l}\text { Well-resourced } \\
\text { laboratory facility } \\
\text { requires }\end{array}$ \\
\hline 7 & FCM & $\begin{array}{l}\text { Detect DNA } \\
\text { damage in } \\
\text { apoptotic cells }\end{array}$ & $\begin{array}{l}\text { Low sensitivity as } \\
\text { compared to FISH }\end{array}$ \\
\hline 8 & GC-MS & $\begin{array}{l}\text { Sensitive to } \\
\text { detect DNA } \\
\text { damage }\end{array}$ & $\begin{array}{l}\text { More estimation of } \\
\text { damage }\end{array}$ \\
\hline
\end{tabular}
by many experimental conditions (Table 1) (Figure $1 \& 2$ ).
Table I Comparison between comet assay and different techniques 
Table Continued..

\begin{tabular}{llll}
\hline $\begin{array}{l}\text { Serial } \\
\text { no }\end{array}$ & Procedures & Advantages & $\begin{array}{l}\text { Disadvantages/ } \\
\text { limitations }\end{array}$ \\
\hline 9 & $\begin{array}{l}\text { Immunological } \\
\text { Assay }\end{array}$ & $\begin{array}{l}\text { Low amount of } \\
\text { DNA requires } \\
\text { Detect DNA } \\
\text { damage in } \\
\text { individual } \\
\text { apoptotic } \\
\text { cells as well as } \\
\text { differentiate } \\
\text { between } \\
\text { apoptosis and } \\
\text { necrosis }\end{array}$ & Costly equipment \\
\hline Comet Assay detected \\
\end{tabular}

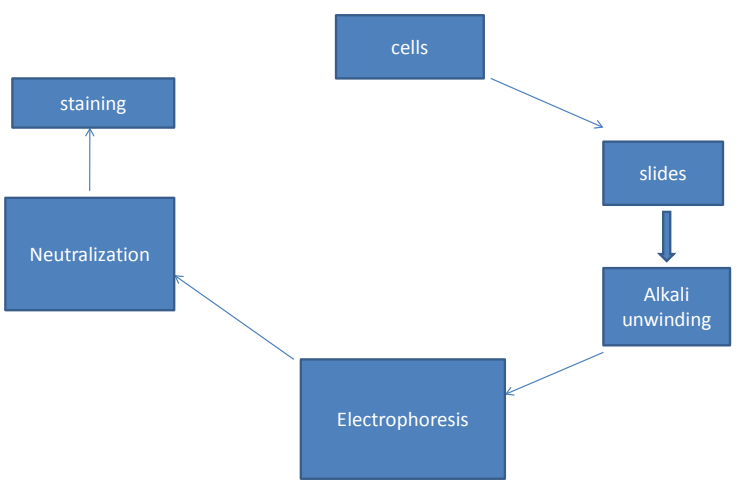

Figure I General scheme of comet assay.

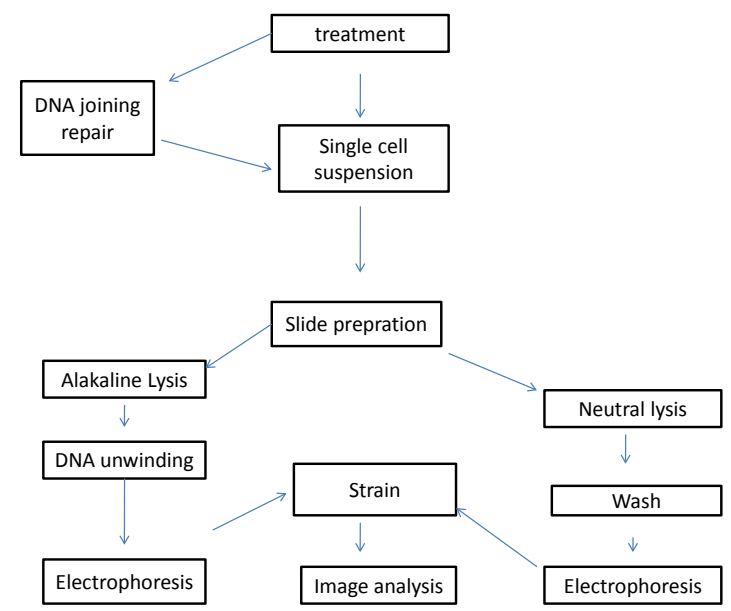

Figure 2 Schematic diagram for different steps in comet assay.

\section{Applications}

\section{Role of comet assay in genotoxicity testing}

Comet assay now a day's used to evaluate the efficacy and safety of pharmaceuticals. ${ }^{4}$ It is easily use for in vivo experiments; tissues can be spread in a single cell suspension; as well as white blood cells (WBCs) provide the material. More sensitivity as well as extra information we get through comet assay. Insertion of repair endonucleases was used for the measurement of specific lesions. Genotoxicity is also evaluate in cell culture system, or with the combination of microsomal "S9" taken from liver that provides enzymes to metabolize the chemicals in a more reactive form. ${ }^{5}$ The comet assay is famous for the evaluation of phytochemicals ability. For example the protection of cells against genotoxic result. ${ }^{6}$

\section{Role of comet assay in chronic and degenerative di- seases}

Comet assay is used for measure DNA damage in target cells; this DNA damage is very useful for the study of diseases like Diabetes mellitus, Rheumatoid arthritis (a joint disease) and also in the study of Alzheimer's and Parkinson's disease. ${ }^{7}$ When we study these diseases through comet assay we seen that high level of SSBs and stress condition were found in a patients, and increased receptiveness as well as efficacy of DNA damage was decreased. ${ }^{7,8}$ The DNA damage in diseases like diabetes, Alzheimer's etc is due to increased oxidative stress or due to direct effect on DNA by different toxic chemical compounds. Alkaline comet assay combined with measurement levels of 8 hydroxy 2 deoxy guanosine was very suitable method for the evaluation of DNA damage due to slight oxidation. ${ }^{7}$

\section{Use of comet assay in male infertility test}

Now a day's more emphasis has been shift towards sperm DNA damage which causes infertility in males. When we study quality of sperm DNA damage in patients we seen that more sperm DNA damage occur in patients having infertility as compares to fertile men, ${ }^{9}$ the cause of sperm DNA damage is due to endogenously derived reactive oxygen species from polyunsaturated fatty acids. Comet assay was found very sensitive technique in the evaluation of DNA damage as compare to other techniques like TUNNEL, HALO assay, flow cytometry etc. ${ }^{9,10} \mathrm{We}$ mention table above in which comparison of comet assay with different techniques has been discussed. The challenges which we are facing while using comet assay for the assessment of sperm DNA damage, are that DNA have a unique structure as compare to other cells. So we need to modify comet assay technique and optimizing conditions. Further study now a days for understanding the mechanism of paternal DNA is under consideration and scientists working on it. ${ }^{11}$

\section{Comet assay role in ecogenotoxicology}

Ecogenotoxicology is basically the study of environmental effects by genotoxin. Genotoxin chemicals can damage genetic material (DNA) of humans and also effects other organisms. Genotoxin chemicals cause pollution in an environment and badly effect the environment. There is a difference between the study of environmental toxicology and epidemiology former ones has focus on species or population level but the later focus on individuals. Some organisms selected as indicators for the detection of toxins for example radioactive compounds, heavy metals which causes harmful effects on human population. The organisms which are selected as indicators are snails, mussels, fish, mice, and some plants as well. Comet assay is use for the monitoring of toxic effects of above mention species. ${ }^{11,12}$ There are many ways for investigation like to carry out laboratory experiments ,organism expose by given them DNA damage agents for the study of sensitivity shown by selected organisms. Specimens should be placed in a clean location so that analysis of DNA damage would be easy.

\section{Comet assay role in genotoxicity of nanoparticles}

Nanoparticles in the past were used in research, development and 
in commercialization, but they had toxicological issue they damage DNA. A lots of mechanisms involve in the ability of nanoparticles for the damage of DNA. These nanoparticles cause oxidative stress but some mechanisms tells us that direct Nanoparticles and DNA connections occur, and causes trouble in mitotic spindle and its components ${ }^{13}$ Size, discharge of toxic ions and ability to generate ROS are the physico-chemical properties important for DNA damaging effects. Nanoparticles can also cause genomic instability by epigenetic mechanisms. ${ }^{14}$ There are many assays available which can be used to detect genotoxicity of nanoparticles. Comet assay help in the measurement of DNA damage as well as DNA repair.

\section{Comet assay use in the study of cancer}

Comet assay is very helpful in the evaluation of carcinogens/ chemicals. ${ }^{15}$ In vivo comet assay is use to differentiate between genotoxic and non genotoxic chemicals which are use in the field of genotoxicology. Comet assay use biomarker and detect DNA damage which is the leading cause of carcinogenicity. Comet assay is a better method as compare to other techniques use for assessment. ${ }^{15}$ DNA damage and defect in DNA repair mechanism cause initiation of pathogenesis and development of cancer. The patients which have cancer, in them increase level of DNA damage and defective repair mechanism can be seen. ${ }^{16-21}$ By finding the level of DNA damage we get information about the nature and harshness of cancer which is helpful for the treatment of cancer and for curing patients from cancer. ${ }^{16}$

\section{Forecast of tumour radio \& chemo sensitivity}

Treatment of cancer depends upon the nature of tumour cells in a patient body. In the past for the study of tumour cells sensitivity towards radiation clonogenic cell survival assay, image of tumour cell by PET scan and single photon emission CT were used. But above mentioned techniques require more time. So we use Comet assay for measuring the sensitivity of tumour cells towards radiation and also in a cells having low proliferation. ${ }^{22}$ Alkaline comet assay could be very helpful for the study of different tumour cell lines like Colon ${ }^{23,24}$ breast $^{25,26}$ prostate. ${ }^{27}$ Alkaline comet assay is also very helpful in the prediction of radio sensitivity of tumour cells and also determine their efficacy. Comet assay is also a sensitive technique for evaluating the use of chemotherapeutic agents in the treatment of cancer. ${ }^{22,28,29}$

\section{Diagnosis}

Comet assay can also be used for diagnosis purpose. For example in a disease named as Nijmegen breakage syndrome which is a autosomal recessive disorder in which genetic instability and cancer occur. With the help of comet assay it is easy to identify Nijmegen syndrome because high level of strand breakage in lymphocytes. ${ }^{30}$ Second disease which is identify through comet assay name as xeroderma pigmentosa. In this disease defect occur in nucleotide excision repair system. Normal UV induced accumulation of DNA strand breaks does not seen in xeroderma pigmentosa, so comet assay use. $^{31}$

\section{Limitations of comet assay}

Comet assay is a sensitive and better technique for DNA damage and also in measure of DNA repair but comet assay also have some limitations.1.small number of sample can be run in a single electrophoresis; it can hold only 20 slides and every slide contain one or two gels. Now changes has been made in comet assay by reducing the gel size. ${ }^{32}$ Automated scoring now requires as compare to simple manual scoring. ${ }^{33}$

\section{Conclusion}

Single cell gel electrophoresis is a simple and rapid method for the study of DNA damage and DNA breaks, now plenty of modified versions available and wide range of cells arranged in the comet assay, makes it very helpful tool for the estimation of extent of DNA damage and repair in various diseases like cancer, Alzheimer, Parkinson's etc. and also in male infertility. It is very sensitive and better technique as compares to other technique like TUNNEL, HPLC etc.

\section{Source of funding}

We declare no source of funding.

\section{Conflict of interest}

The author declares no conflict of interest.

\section{References}

1. Ostling O, Johanson KJ. Microelectrophoretic study of radiation-induced DNA damages in individual mammalian cells. Biochem Biophys Res Commun. 1984;123(1):291-298.

2. Olive PL. Cell proliferation as a requirement for development of the contact effect in Chinese hamster V79 spheroids. Radiat Res. 1989;117(1):79-92.

3. Singh NP, Mc Coy MT, Tice RR, et al. A simple technique for quantitation of low levels of DNA damage in individual cells. Exp Cell Res. 1988;175(1):184-191.

4. Hartmann A, Agurell E, Beevers C, et al. Recommendations for conducting the in vivo alkaline comet assay. $4^{\text {th }}$ International Comet Assay Workshop. Mutagenesis. 2003;18(1):45-51.

5. Tice RR, Agurell E, Anderson D, et al. Single cell gel/comet assay: guidelines for in vitro and in vivo genetic toxicology testing. Environ Mol Mutagen. 2000;35(3):206-221.

6. Duthie SJ, Dobson VL. Dietary flavonoids protect human colonocyte DNA from oxidative attack in vitro. Eur J Nutr. 1999;38(1):28-34.

7. Collins A, Koppen G, Valdiglesias V, et al. The comet assay as a tool for human biomonitoring studies: the Com Net Project. Mutat Res Rev Mutat Res. 2014;759:27-39.

8. Liao W, Mc Nutt MA, Zhu WG. The comet assay: A sensitive method for detecting DNA damage in individual cells. Methods. 2009;48(1):46-53.

9. Lewis SE, Agbaje IM. Using the alkaline comet assay in prognostic tests for male infertility and assisted reproductive technology outcomes. $M u$ tagenesis. 2008;23(3):163-170.

10. Evenson DP, Kasperson K, Wixon RL. Analysis of sperm DNA fragmentation using flow cytometry and other techniques. Soc Reprod Fertil. 2007;65:93-113.

11. Jha AN. Ecotoxicological applications and significance of the comet assay. Mutagenesis. 2008;23(3):207-221.

12. Punit Kumar Dhawan. Ultrasonic and thermo physical properties of nano particles based engineering materials. India; Shodhganga; 2013.

13. Magdolenova Z, Collins A, Kumar A, et al. Mechanisms of genotoxicity. A review of in vitro and in vivo studies with engineered nanoparticles. Nanotoxicology. 2014;8(3):233-278.

14. Stoccoro A, Karlsson HL, Coppedè F, et al. Epigenetic effects of nanosized materials. Toxicology. 2013;313(1):3-14. 
15. Kang SH, Kwon JY, Lee JK, et al. Recent advances in in vivo genotoxicity testing: prediction of carcinogenic potential using comet and micronucleus assay in animal models. J Cancer Prev. 2013;18(4):277-288.

16. Mc Kenna DJ, Mc Keown SR, Mc Kelvey-Martin VJ. Potential use of the comet assay in the clinical management of cancer. Mutagenesis. 2008;23(3):183-190.

17. Moneef MA, Sherwood BT, Bowman KJ, et al. Measurements using the alkaline comet assay predict bladder cancer cell radio sensitivity. $\mathrm{Br} J$ Cancer. 2003;89(12):2271-2276.

18. Schabath MB, Spitz MR, Grossman HB, et al. Genetic instability in bladder cancer assessed by the comet assay. J Natl Cancer Inst. 2003;95(7):540-547.

19. Kopjar N, Milas I, Garaj-Vrhovac V, et al. Alkaline comet assay study with breast cancer patients: evaluation of baseline and chemotherapy-induced DNA damage in non-target cells. Clin Exp Med. 2006;6(4):177-190

20. Santos RA, Teixeira AC, Mayorano MB, et al. Basal levels of DNA damage detected by micronuclei and comet assays in untreated breast cancer patients and healthy women. Clin Exp Med. 2010;10(2):87-92.

21. Shahidi M, Mozdarani H, Mueller WU. Radio sensitivity and repair kinetics of gamma-irradiated leukocytes from sporadic prostate cancer patients and healthy individuals assessed by alkaline comet assay. Iran Biomed J. 2010;14(3):67-75.

22. Azqueta A, Collins AR. The essential comet assay: a comprehensive guide to measuring DNA damage and repair. Arch Toxicol. 2013;87(6):949-968.

23. Novotná B. Increased DNA fragmentation detected by comet assay in peripheral blood of heterozygotes for a frameshift mutation in the DNA repair protein nibrin. Europe: Slovakia, DNA Repair Workshop Smolenice; 2000. 33 p.
24. Green MH, Lowe JE, Harcourt SA, et al. UV-C sensitivity of unstimulated and stimulated human lymphocytes from normal and xeroderma pigmentosum donors in the comet assay: A potential diagnostic technique. Mutat Res. 1992;273(2):137-144.

25. Shaposhnikov S, Azqueta A, Henriksson S, et al. Twelve-gel slide format optimised for comet assay and fluorescent in situ hybridisation. Toxicol Lett. 2010;195(1):31-34.

26. Gutzkow KB, Langleite TM, Meier S, et al. High-throughput comet assay using 96 minigels. Mutagenesis. 2013;28(3):333-340.

27. Azqueta A, Gutzkow KB, Brunborg G, et al. Towards a more reliable comet assay: optimising agarose concentration, unwinding time and electrophoresis conditions. Mutat Res. 2011;724(1-2):41-45.

28. Sunitha Kumari, Rajesh PR, Kanchan LS, et al. DNA damage: Detection strategies. EXCLI J. 2008;7:44-62.

29. Azqueta A, Shaposhnikov S, Collins AR. DNA repair measured by the comet assay. In: Inna Kruman, editor. DNA Repair. InTech, Europe; 2011. p. 1-23.

30. Gaivão I, Piasek A, Brevik A, et al. Comet assay-based methods for measuring DNA repair in vitro; estimates of inter-and intra-individual variation. Cell Biol Toxicol. 2009;25(1):45-52.

31. Collins AR, Dusinská M, Horváthová E, et al. Inter-individual differences in repair of DNA base oxidation, measured in vitro with the comet assay. Mutagenesis. 2001;16(4):297-301.

32. Mutlu AG. Measuring of DNA damage by quantitative PCR. In: Patricia Hernandez-Rodriguez, editor. Polym Chain React. Europe: In Tech; 2012. $566 \mathrm{p}$

33. Kurasaki M, Sun Y, Komori M, et al. Toshiyuki hosokawa measurement of DNA damage by terminal deoxynucleotidyl transferase reaction. $A d v$ Biol Chem. 2012;2(3):243-247. 